\title{
ZNAČAJ I ULOGA USTAVNOG SUDA U DEMOKRATSKOJ TRANZICIJI - PRIMJER JUŽNOAFRIČKE REPUBLIKE
}

\author{
UDK: 34. $565.2(680)$ \\ Primljeno: 10. VIII. 2018. \\ Pregledni znanstveni rad
}

\begin{abstract}
Ustavni sud, još od vremena uvođenja ove institucije u pravni sustav, ima značajnu ulogu u ustavno-pravnom sustavu. S vremenom značaj ove institucije se povećavao. Tako Ustavni sud polako postaje nezaobilazan akter u kreiranju najvažnijih političkih i pravnih procesa u državi. Jedan od najočitijih primjera ovakvog širokog značaja Ustavnog suda je slučaj demokratske tranzicije u Južnoafričkoj Republici tijekom 90-ih godina prošloga stoljeća. Naime, tada je Ustavni sud Južnoafričke Republike imao jednu od glavnih uloga u usmjeravanju, ali i kreiranju novoga ustavnopravnog okvira koji je za svrhu imao osigurati uspješnu tranziciju. Zapravo, može se kazati, da je sam Ustavni sud sudjelovao u kreiranju novoga ustavnog uređenja, što svakako predstavlja raritetan primjer ovakve uloge ove institucije u cijelom procesu ustavne izgradnje određene države. Naravno, pored Ustavnog suda uspostavljeni su i drugi institucionalni i pravni mehanizmi u svrhu što lakšeg i uspješnijeg prijelaza iz sustava apartheida u demokraciju. Mnogi od njh su preuzeti iz drugih sustava te prilagođeni potrebama i društvenim okolnostima Južnoafričke Republike. Sukladno tome, iskustvo ove države i njena rješenja mogu poslužiti kao uzor drugim državama koje se nalaze u postupku vlastite demokratske tranzicije.
\end{abstract}

Ključne riječi: Ustavni sud, Južnoafrička Republika, tranzicija, ustav, ustavna načela

\section{UVOD}

Donošenje novoga ustava najčešće predstavlja jedan od prvih koraka $u$ institucionalnom i pravnom preuređenju određene države jer se upravo njime država identificira prema drugima u suvremenom svijetu. ${ }^{1}$ To je i razumljivo, budući da ustav kao najviši pravni akt određuje same temelje državnog i društvenog uređenja. ${ }^{2}$ Ma koliko god bio dugotrajan i zahtjevan proces izrade novog ustavnog dokumenta, on predstavlja tek početak. Primjena u praksi novih pravnih i institucionalnih rješenja sljedeći je važan korak u tome smjeru. Međutim, mnogo puta dogodit će se da taj drugi korak zatraži puno više vremena i strpljenja nego li prvi. Posebno će biti tako u situaciji kada u nekoj političkoj zajednici određeni akteri nisu voljni prihvatiti promjene koje novi ustav donosi. Razloga za to može biti više, a jedan od njih

1 Arsen Bačić: Ustavno pravo i političke institucije - studijski izvori, Pravni fakultet u Splitu, 2008., Split, str. 60.

2 Branko Smerdel: Ustavno uređenje europske Hrvatske, Narodne novine, 2013., Zagreb, str. 3. 
svakako je i nespremnost za nagle promjene. Stoga bi mudro postupili oni koji žele dovesti promjene u određenu državu kada bi to činili u malim koracima i postupno. Naravno, u određenom trenutku mora se načiniti „rez“ koji će označiti prekid sa starim i dolazak novoga, jer odugovlačenje s nužnim promjenama situaciju samo čini težom, a traume zbog raskida s prošlim potencijalno većim. Međutim, način i postupak izvođenja toga ,reza“ za njegovu uspješnost imaju odlučujući značaj.

Primjer Južnoafričke Republike (dalje: JAR) s početka 90-ih godina prošloga stoljeća dobro oslikava navedenu situaciju. Naime, ta država se u to vrijeme već suočila s tim da se tadašnje uređenje više ne može, niti smije, trpjeti i da su promjene koje će označiti raskid s prošlošću aparthejda nužne. Međutim, koliko god očito bilo da se to mora učiniti, toliko je bilo jasno da to nije ni najmanje jednostavan zadatak. Valjalo je načiniti taj „rez“, ali na način da država ne izgori u želji onih koji promjene hoće i ne iskrvari u otporu onih koji bi promjene htjeli zaustaviti. Kao što ćemo vidjeti u nastavku teksta, navedenih potreba kao i opasnosti koje dolaze s njima bili su itekako svjesni oni na kojima je bio zadatak provesti promjenu. Pri ovom složenom zahvatu poslužili su se mnogobrojnim institucionalnim i pravnim rješenjima koji su imali zadatak osigurati uspjeh tranzicije. Naravno, pri svemu tome od velike je koristi bilo i komparativno iskustvo drugih država koje su prolazile kroz slične procese transformacije i tranzicije. Međutim, neka od rješenja primijenjena u slučaju JAR-a mogu i sama poslužiti kao uzor za neke druge države kojima tek predstoji poći tranzicijskim putem. Možda prije svega tu možemo uzeti primjer uporabe institucije ustavnog suda kao s jedne strane sukreatora, a s druge strane nadzornika provedbe novih ustavnih rješenja.

\section{JUŽNOAFRIČKA REPUBLIKA IZLAZI IZ RAZDOBLJA APARTHEJDA}

\subsection{Uloga ustavnog sudstva u pravno-političkom sustavu}

Povijest institucije ustavnog suda počinje još od vremena prije Drugog svjetskog rata, a njegovo uvođenje u pravni sustav zagovarao je Hans Kelsen. ${ }^{3}$ Ustavni sud kao institucija u čiju nadležnost ulazi nadzor nad ustavnošću akata drugih tijela vlasti, koja na taj način oživotvoruje Kelsenovu ideju o ustavnom sudu kao „čuvaru

\footnotetext{
Debata između Hansa Kelsena s jedne strane te Carla Schmitta s druge strane o tome tko bi trebao biti „čuvar ustava“ vodila se tijekom razdoblja između dva svjetska rata. Ukratko, za Kelsena tu ulogu trebao bi preuzeti ustavni sud kao posebna i neovisna institucija, dok je Schmitt zastupao tezu da bi takva uloga trebala pripasti predsjedniku države kojeg bira neposredno narod na izborima. Naravno, na ovome mjestu ne možemo ulaziti u pojedinosti i argumentaciju navedene debate te stoga čitatelja za detalje upućujemo na naslov: Lars Vinx: The Guardian of the Constitution - Hans Kelsen and Carl Schmitt on the Limits of Constitutional Law, Cambridge University Press, 2015.
} 
ustava“, počela je prevladavati u Europi nakon 1945. g. Ipak, valja imati na umu kako se tijekom vremena i shvaćanje o ulozi ustavnog suda počelo mijenjati te on počinje dobivati sve veću ulogu i na području kreiranja politike u državi. ${ }^{5}$ Takvu aktivniju poziciju počinju zauzimati i ustavni sudovi, primjerice, zemalja središnje i istočne Europe koje se nalaze na putu tranzicije u demokraciju. ${ }^{6}$ Na taj način ustavni sudovi postaju aktivan i značajan čimbenik u funkcioniranju, ali i u samom procesu oblikovanja određenog pravno-političkog sustava.

Dakle, institucija ustavnog suda počinje prelaziti onu tanku granicu između pravnog i političkog te sve česće uzima učešća u usmjeravanju i oblikovanju političkih procesa. Ustavni sud polako postaje institucija s kojom treba računati bilo koja politička opcija prilikom kreiranja i implementiranja svojih političkih ciljeva, jer upravo ovaj sud dobiva pravo, ali i dužnost, suspendirati i ukinuti djelovanje političkih aktera koje izlazi izvan zadanog ustavnog okvira. Ustavni sud Južnoafričke Republike (dalje: Ustavni sud) i njegova uloga u procesu demokratske tranzicije te zemlje koju je na polju ustavnog prava prije svega obilježilo donošenje dvaju ustava (najprije Provizornog Ustava 1993. g., a potom i Ustava iz 1996.) zasigurno je jedan od boljih primjera za takvu ulogu ustavnog sudstva u političkom procesu. Navedeni Ustavni sud ovdje je odigrao ne samo ulogu ,čuvara ustava“ nego je i sam imao udjela u stvaranju novog ustavnog okvira čime je i sam postao sukreator ustava koji mu je povjeren na „,̌̌vanje“. Upravo o ovoj ulozi Ustavnog suda u početnoj fazi procesa demokratske tranzicije JAR-a bit će više riječi u nastavku teksta.

\subsection{Donošenje Provizornog Ustava 1993. g.}

Početkom 90-ih godina prošloga stoljeća Južnoafrička je Republika počela s tranzicijom iz sustava aparthejda u ustavno-demokratsku državu u kojoj se njeguju načela $\mathrm{i}$ vrednote vladavine prava. Naravno da je u tome procesu bilo potrebno izmijeniti i ustavni okvir države na način da se on uskladi s novonastalim promjenama na političkoj pozornici. Ipak, prije nego li prijeđemo na navedene izmjene u ustavnoj strukturi, potrebno je u kratkim crtama navesti spomenute promjene u političkodruštvenoj sferi, jer upravo je promjena paradigme u politici i društvu uzrokavala i ovdje, kao što je to obično slučaj i drugdje, usklađivanje ustavnog uređenja s novonastalom situacijom. Na taj način određuju se glavne odrednice budućeg željenog kretanja i razvoja procesa u društvu i državi.

Već se 20. rujna 1989. godine, inauguracijom Frederika Willema de Klerka, predsjednika vladajuće Nacionalne stranke (National Party, dalje: NP) u novog

4 Bojan Bugarič: Courts as Policy-Makers: Lessons from Transition, 42 Harv. Int'1 L. J. 247 (2001.), str. 251, preuzeto sa: http://heinonline.org/HOL/Page?handle=hein.journals/hilj42\&collection=journals\& $\mathrm{id}=253 \&$ startid=\&endid=294 - 28. II. 2018. g.

5 Ibidem, str. 251.

6 Ibidem, str. 261. 
predsjednika JAR-a dalo naslutiti kako će se stvari uskoro početi mijenjati. ${ }^{7}$ Vrijeme će pokazati da su te slutnje bile itekako opravdane. Naime, nakon desetljeća provedenih u aparthejdu pod budnom paskom NP-a došlo je do zaokreta u pristupu unutar same vladajuće elite. Predsjednik de Klerk shvatio je kako je došlo vrijeme za napuštanje aparthejda i za uvažavanje u reformama snage i političke volje dotada obespravljenog crnačkog stanovništva. A takva potreba za međusobnom suradnjom između dotada, i to ne samo politički, suprotstavljenih strana bila je uzajamna. ${ }^{8}$ Konačna potvrda opredijeljenosti novoga predsjednika, kao i vladajućeg NP-a, za napuštanje aparthejda i ugnjetavanja crnačkog stanovništva, uslijedila je 2 . veljače 1990. g. kada je donesno nekoliko važnih odluka koje su otvorile put demokraciji i slobodi. Među najvažnijima su svakako ukidanje zabrana pojedinih političkih stranaka, ali i puštanje na slobodu političkih zatvorenika, od kojih je najzvučnije svakako ime Nelsona Rolihlahle Mandele. ${ }^{9}$ Dakle, otada Afrički nacionalni kongres (African National Congress, dalje: ANC), kao i upravo oslobođeni Mandela, dobiva mogućnost sudjelovati na političkoj sceni JAR-a. U sljedećem razdoblju traju pregovori relevantnih političkih aktera u vezi s uspostavljanjem novog ustavnog okvira koji će i na formalnopravnom planu označiti otvaranje JAR-a demokraciji i svim njenim vrijednostima. Vodeću ulogu u tome igrali su upravo predsjednik države F. W. Klerk te oslobođeni Mandela. Inicijalni sastanak između ANC-a i vlade održan je u svibnju 1990. g., a uskoro je održano još nekoliko važnih sastanaka i postignuto nekoliko dogovora koji su svakako pridonijeli stabilizaciji situacije u zemlji. Sljedeći iznimno bitan događaj desio se krajem prosinca 1991. g. kada su održane prve višestranačke konzultacije glede budućeg ustavnog uređenja pod nazivom Kongres za demokratsku Južnu Afriku (eng. Congress for a Democratic South Africa; u nastavku: CODESA). Sljedeća godina donijet će nove izazove i poteškoće u postupku transformacije JAR-a u ustavno-demokratsku državu. Tako sastanak CODESA 2 u svibnju 1992. g. nije rezultirao potpunim uspjehom, ali ipak o nekim važnim stvarima postignut je dogovor. Međutim, napori za postizanjem konačnog dogovora nisu jenjavali te su, unatoč svim poteškoćama, nastavljeni višestranački pregovori za usvajanje novog ustavnog okvira. ${ }^{10}$

Navedeni pregovori rezultirali su dogovorom o datumu održavanja prvih demokratskih izbora u državi (izbori su predviđeni za 27. travnja 1994. g.), a potom je, između ostaloga, usuglašen i konačni tekst Provizornog Ustava koji je Parlament usvojio, pod službenim nazivom: „Constitution of the Republic of South Africa Act

Gretchen Carpenter: The Republic of South Africa Constitution Act 200 of 1993 - an overview, SA Publiekreg = SA Public Law, Volume 9, Issue 2, Jan 1994, p. 222-232, str. 222; preuzeto sa: https:// journals.co.za/content/sapr/9/2/AJA02586568_96 - 23. I. 2018. g.

8 David Welsh: South Africa's Democratic Transition, 2 Brown J. World Aff. 221 (1994.), str. 221222; preuzeto sa: http://heinonline.org/HOL/Page?handle=hein.journals/brownjwa2\&div=34\&start page $=221 \&$ collection $=$ journals\&set_as_cursor $=3 \&$ men_tab $=$ srchresults -23 . I. 2018. g.

9 Gretchen Carpenter: op. cit. (bilj.7.), str. 222.

10 D. J. Brand: Constitutional Reform - The South African Experience, 33 Cumb. L. Rev. 1 (2002.), str. 6-7, preuzeto sa: http://heinonline.org/HOL/Page?handle=hein.journals/cumlr33\&collection=journals $\& \mathrm{id}=9 \&$ startid $=\&$ endid $=22-23$. I. 2018. g. 
200 of 1993 “. ${ }^{11}$ Ovaj Provizorni Ustav bio je zamišljen tek kao prijelazno rješenje koje će poslužiti kao osnova za daljnju demokratizaciju društva. Kako smo već napomenuli, dogovoreni datum prvih višestranačkih demokratskih izbora bio je 27. travnja 1994. g. Sukladno rezultatima tih izbora, formiran je Parlament koji je dobio ovlast (ali i dužnost) ustavotvorca - u roku od dvije godine trebao je usvojiti novi Ustav koji će biti u skladu s ustavnim načelima koje sadrži Provizorni ustav. Ta ustavna načela jamčila su da će novi ustavni dokument poslužiti kao temelj za uspostavu vladavine prava s podjelom vlasti uz neovisno sudstvo koje dobiva priliku, ali obvezu, biti „čuvar ustava“. Uza sve to, zajamčena je i zaštita temeljnih prava i sloboda. ${ }^{12}$ Nadalje, ta ustavna načela određivala su i supremaciju ustavnog dokumenta u hijerarhiji pravnih propisa te, sukladno tome, sudski nadzor ustavnosti i zakonitosti. ${ }^{13}$ Ukratko, iako je ovaj Provizorni ustav zamišljen kao prijelazno rješenje, to ni na koji način nije utjecalo na njegovu pravnu snagu i značaj, predstavljao je najviši pravni akt zemlje te su njime bile obvezane sve grane državne vlasti i sva državna tijela. ${ }^{14}$

\subsection{Provizorni ustav i Ustavni sud Južnoafričke Republike}

Provizornim ustavom uspostavljen je Ustavni sud Južnoafričke Republike (dalje: Ustavni sud), sa sjedištem u Johannesburgu, koji se sastojao od 11 sudaca biranih na vrijeme od sedam godina bez mogućnosti reizbora. Formalna ovlast za imenovanje sudaca Ustavnog suda bila je u rukama predsjednika države, ali on tu ovlast nije provodio samostalno nego uvijek uz sudjelovanje drugih aktera. Tako je četvoricu ustavnih sudaca predsjednik imenovao iz reda sudaca Vrhovnog suda, ali uz savjetovanje s Vladom i predsjednikom Vrhovnog suda. Nadalje, šest sudaca Ustavnog suda isto tako imenuje predsjednik države, uz savjetovanje s Vladom, s liste kandidata koje predsjedniku predlaže Sudska komisija (vrhovno tijelo sudbene vlasti u JAR-u). Jedanaesti je član Ustavnog suda njegov predsjednik kojega izravno i samostalno imenuje predsjednik države..$^{15}$

Prema odredbama Provizornog ustava, „Ustavni sud je vrhovna instanca kada je u pitanju tumačenje, zaštita i primjena ovoga Ustava“.${ }^{16} \mathrm{U}$ nastavku istog članka

11 Opširnije o cjelokupnom tijeku navedenih pregovora i njihovim rezultatima vidi u: Gretchen Carpenter: op. cit. (bilj. 7.), str. 222-227.

12 D. J. Brand: op. cit. (bilj. 10.), str. 8-9.

13 Christina Murray: A Constitutional Beginning: Making South Africa's Final Constitution, 23 UALR L. Rev. 809 (2001.), str. 814; preuzeto sa: http://heinonline.org/HOL/Page?handle=hein.journals/ ualr $23 \&$ collection $=$ journals $\&$ id $=819 \&$ startid $=\&$ endid $=848-23$. I. 2018. g.

14 Za detaljniji prikaz sadržaja Provizornog ustava vidi: Hugh Corder, Towards a South African Constitution, 57 Mod. L. Rev. 491 (1994.), str. 511-521; preuzeto sa: http://heinonline.org/HOL/ Page?handle $=$ hein.journals $/$ modlr57\& collection $=$ journals\&id $=509 \&$ startid $=\&$ endid $=551-23$. I. 2018. $\mathrm{g}$.

15 Jeremy Sarkin, The Political Role of the South African Constitutional Court, 114 S. African L.J. 134, str. 136-137; preuzeto sa: http://heinonline.org/HOL/Page?handle=hein.journals/soaf114\&collection $=$ journals $\& \mathrm{id}=144 \&$ startid $=\&$ endid $=160-23$. I. 2018. $\mathrm{g}$.

16 Čl. 98. st. 2. Provizornog ustava (prijevod autora), preuzeto sa: https://www.gov.za/ documents/constitution/constitution-republic-south-africa-act-200-1993\#THE\%20JUDICIAL\%20 
nabrojane su nadležnosti Ustavnog suda među koje, između ostaloga, ulazi zaštita sloboda i prava građana zajmčena tim ustavom, rješavanje u sporovima između tijela državne vlasti, nadziranje ustavnosti zakona, ali i akata izvršne vlasti i uprave. Odluke Ustavnog suda obvezujuće su za sva tijela sudbene, izvršne i zakonodavne vlasti, ali i za sve druge osobe. Ipak, osobito značajna nadležnost Ustavnog suda bila je ona sadržana u čl. 71. st. $2 .{ }^{17}$ Provizornog ustava, a odnosila se na ovlast Ustavnog suda da potvrdi kako je tekst novoga Ustava (dakle, onog Ustava što ga Parlament mora donijeti u roku od dvije godine) u skladu s ustavnim načelima navedenima u Provizornom ustavu. Dakle, predviđeno je da Ustavni sud ima ,zadnju riječ“ kada je u pitanju donošenje novog Ustava, jer bez njegove potvrde novi Ustav ne može stupiti na snagu. Iz svega naprijed navedenoga može se zaključiti kako je u postupku donošenja novog Ustava Ustavni sud zapravo dobio odlučujuću ulogu u predstojećem, finalnom koraku ustavnog procesa koji bi trebao rezultirati donošenjem novog Ustava koji će zamijeniti Provizorni ustav iz 1993. g. Pri tome Ustavni sud ne samo da ima značajnu ulogu, nego, štoviše, kako smo već kazali, postaje odlučujući čimbenik pa i sukreator ustava, jer odluka Parlamenta o izglasavanju novog ustava nema pravnu snagu bez potvrde Ustavnog suda o sukladnosti novog Ustava s načelima proklamiranima u odredbama Provizornog ustava. U nastavku teksta uvjerit ćemo se u važnost ove uloge Ustavnog suda.

\section{DONOŠENJE NOVOG USTAVA JAR-A 1996. G.}

\subsection{Rad ustavotvorca na novom Ustavu iz 1996. g.}

Nakon formiranja Parlamenta sukladno izbornim rezultatima 1994. godine, zakonodavno je tijelo počelo ispunjavati i svoje ustavotvorne dužnosti. Rasprava i pregovori o novom Ustavu započeli su. Ipak, cijeli taj proces nije bio ni najmanje jednostavan ni lagan, što je i razumljivo ako uzmemo u obzir zadatak koji je stajao pred ustavotvorcem - postavljanje stabilnog i trajnog pravno-institucionalnog okvira koji će omogućiti konačan prijelaz iz sustava aparthejda u sustav koji će postaviti okvir za ustavno-demokratski razvoj države. Složenost ovog zadatka proizlazi i iz same organizacijske strukture ustavotvornog procesa. Već je kazano da su dva glavna aktera bili Parlament koji će donijeti novi Ustav te Ustavni sud bez čije potvrde novi Ustav ne može stupiti na snagu. Tako je na razini samog Parlamenta, čija su dva doma bila sastavljena od 490 članova, ${ }^{18}$ izvršena daljnja diferencijacija s

AUTHORITY\%20AND\%20THE\%20ADMINISTRATION\%20OF\%20JUSTICE - 23. I. 2018. g.

17 Preuzeto sa: https://www.gov.za/documents/constitution/constitution-republic-south-africa-act200-1993\#THE\%20JUDICIAL\%20AUTHORITY\%20AND\%20THE\%20ADMINISTRATION\%20 OF\%20JUSTICE - 23. I. 2018. g.

18 Hassen Ebrahim, Laurel E. Miller: „Creating the Birth Certificate of a New South Africa Constitution Making after Apartheid“ u: Laurel E. Miller, Louis Aucoin (ed.): Framing the State in Times of Transition - Case Studies in Constitution Making, str. 128., United States Institute of Peace Press, 
ustrojavanjem, unutar i u okviru njega, drugih manjih tijela i odbora, uz istovremeno uključivanje javnosti u taj proces. ${ }^{19}$ Upravo su ova manja tijela svojom većom mobilnošću i efikasnošću trebala omogućiti izvršenje ustavotvorne zadaće do 8. svibnja 1996. g. koji je odredbama Provizornog ustava postavljen kao krajnji rok za usvajanje novog Ustava. ${ }^{20}$

Takvim organiziranjem ustavotvornog procesa i sam je ustavotvorac pokazao kako razumije važnost i složenost zadaće koja je postavljena ispred njega, ali i vremenskog okvira u kojem ona mora biti izvršena. A vrijeme nije bilo njegov saveznik. Ipak na zadnji dan roka, sat vremena prije njegova isteka, ustavotvorna skupština usvojila je novi Ustav ${ }^{21}$ koji je, prema riječima Cyrila Ramaphose, predsjedavajućeg Ustvotvornom skupštinom, trebao predstavljati ,rodni list nove južnoafričke nacije.“22 Ipak, posljednju riječ u ovom „rađanju nacije“ imao je Ustavni sud čiji je zadatak bio ovjeriti rukopis ustavotvorca uobličen u tekst Ustava. Međutim, kako ćemo uskoro i vidjeti, Ustavni sud novonapisani „rodni list“ ipak nije smatrao dostojnim njegove potvrde.

\subsection{Ustavni sud kao kontrolor ustavotvorca, ali i suustavotvorac}

Već smo naveli kako odredba čl. 71. st. 2. Provizornog ustava dodjeljuje Ustavnom sudu konačnu odluku u postupku donošenja novog Ustava. Nadalje, odluka Ustavnog suda o ovom pitanju konačna je i obvezujuća (čl. 71. st. 3. Provizornog ustava). Iščitavajući ove odredbe nije teško izvući zaključak kako je Ustavni sud u konkretnom slučaju postao zapravo sukreator novog Ustava odnosno njegov koautor. Ovakva pozicija i uloga Ustavnog suda u ustavotvornom postupku predstavlja ,presedan“23 ili, slikovitije kazano, uloga Ustavnog suda u ovom procesu označena je kao „Alisa u zemlji čudesa.“24 Doista, ovakve ovlasti ustavnoga suda zasigurno nisu uobičajene u povijesti procesa donošenja novih ustava. Ovdje njegova uloga počinje i prije stupanja na snagu Ustava. Dakle, njegova uloga nije bila u tome da zaštiti poziciju Ustava kao superiornog pravnog akta i vrijednosti izražene u njemu. On, naprotiv, sudjeluje u samom postupku njegova donošenja, vodeći računa o tome da taj Ustav bude vrijedan njegove zaštite u budućnosti. U protivnom, uskratit će mu dozvolu za postojanje.

Washington, D.C., 2010., preuzeto sa: https://www.usip.org/sites/default/files/Framing\%20the\%20State/ Chapter5_Framing.pdf - 16. II. 2018. g. 139.

19 Detaljnije o uključivanju javnosti u ovaj proces donošenja novog Ustava vidjeti u: Ibidem, str.133-

20 Opširnije o tome u: Ibidem, str.128-129.

21 Ibidem, str. 133.

22 Navedeno prema: Ibidem, str. 132.

23 Ibidem, str. 139-140. H. Ebrahim i L. E. Miller na ovom mjestu dalje upućuju na: Samuel Issacharoff: „Constitutionalizing Democracy in Fractured Societies“, Journal of International Affairs, vol. 58, no. 1 (Fall 2004), p. 83. i Richard Spitz, Matthew Chaskalson: The Politics of Transition: A Hidden History of South Africa's Negotiated Settlement, Oxford: Hart Publishing (2000.), p. 427.

24 Christina Murray: op. cit. (bilj. 13), str. 814. 
Ustavni sud, odlučujući o prijedlogu ustavnog teksta usvojenog u Parlamentu 8. svibnja 1996. g., takvu je dozvolu uskratio svojom Odlukom od 6. rujna 1996. g. (Certification of the Constitution of the Republic of South Africa, 1996, Case 23/96), ${ }^{25}$ (dalje: Odluka).

U navedenoj Odluci utvrdio je kako tekst novog Ustava nije sukladan načelima sadržanima u Provizornom ustavu. Tako je, primjerice, utvrđeno da je za pojedine zakone onemogućena kontrola njihove ustavnosti, nadalje, nadležnost, organizacijska struktura i financijska samostalnost lokalnih nivoa vlasti nisu uređene na zadovoljavajući način, kao ni samostalnost i neovisnost institucija Državnog odvjetnika i Pučkog pravobranitelja. Isto tako, ni postupak za promjenu ustava nije uređen na zadovoljavajući način, a nije osigurana ni zaštita ustavom zajamčenih temeljnih sloboda i prava na način da budu izuzeta (dakle zaštićena) od budućih ustavnih promjena. ${ }^{26} \mathrm{Na}$ temelju ovakvog pravorijeka Ustavnog suda, tekst Ustava vraćen je Ustavotvornoj skupštini na doradu i ispravak uočenih nedostataka. Ustavotvorna skupština ubrzo je pristupila usklađivanju teksta Ustava s Odlukom te je nakon izvršenih promjena ponovno podnijela tekst Ustava na potvrdu Ustavnom sudu. Ovaj put Ustavni sud u svojoj Odluci od 4. prosinca 1996. g. (Certification of the Amended Text of the Constitution of the Republic of South Africa, 1996, Case CCT 37/96 $)^{27}$ utvrdio je kako više nema zapreke stupanju na snagu novog Ustava. Tako je konačno stvoren „rodni list nove južnoafričke nacije“. Predsjednik JAR-a potpisao ga je 10. prosinca 1996. g., a stupio je na snagu 4. veljače 1997. g. ${ }^{28}$

\section{ULOGA USTAVNIH MEHANIZAMA U DEMOKRATSKOJ TRANZICIJI}

\subsection{Ustavno-demokratska ,tranzicija u dva koraka“(29}

Iz gore opisanog procesa tranzicije iz sustava aparthejda u sustav koji počiva na ustavno-demokratskim temeljima u slučaju JAR-a vidljivo je da se isti odvijao u dva koraka. Prva je faza završena donošenjem Provizornog ustava, a konstituiranjem prvog demokratski izabranog Parlamenta u prvoj polovici 1994. g. otpočinje

${ }_{25}$ Cijeli tekst Odluke 6. rujna 1996. g. dostupan na: http://www.saflii.org/za/cases/ZACC/1996/26. pdf - 17. II. 2018. g.

26 Detaljnije u: Hassen Ebrahim, Laurel E. Miller: op. cit. (bilj. 18), str. 155.

27 Cijeli tekst Odluke od 4. prosinca 1996. g. dostupan na: http://www.saflii.org/za/cases/ ZACC/1996/24.pdf - 17. II. 2018. g.

28 Christina Murray: Negotiating beyond Deadlock: From the Constitutional Assembly to the Court, 32 Int'l J. Legal Info. 322 (2004.), str. 348; preuzeto sa: http://heinonline.org/HOL/Page?handle=hein. journals/ijli32\&collection $=$ journals $\&$ id $=368 \&$ startid $=\&$ endid $=396-17$. II. 2018. $\mathrm{g}$.

${ }^{29}$ Hugh Corder: op. cit. (bilj. 14); str. 491, Hassen Ebrahim, Laurel E. Miller: op. cit. (bilj. 10), str. 121. 
druga faza koja uspješno završava donošenjem novoga Ustava krajem 1996. g. ${ }^{30}$ Zasigurno je ovakav pristup procesu demokratske tranzicije iziskivao mnogo truda i vremena. ${ }^{31}$ Međutim, takav pristup bio je itekako opravdan iz nekoliko razloga. Najprije, ovakav pristup bio je uvjetovan ostavštinom aparthejda i svim njegovim negativnim i razarajućim učincima na društvo u cjelini. Naravno, sve se to zasigurno odrazilo i na sam proces političkih pregovora povezanih uz demokratsku tranziciju društva, naročito ako imamo u vidu krhkost i nestalnost ovoga procesa i njegovih rezultata ako se njemu ne pristupi pažljivo i temeljito što posebno do izražaja dolazi u uvjetima socijalne podijeljenosti kakva je postojala u to vrijeme u JAR-u. ${ }^{32}$ Uostalom, režim aparthejda ostavio je takve traume na pojedine društvene grupe koje, u svojoj borbi protiv njegova zla i u svrhu uspostave vlastite dominacije, nisu prezale ni od toga da uzvrate jednakom mjerom. ${ }^{33}$ Naravno, to nije iscrpan prikaz svih specifičnosti društvenih datosti južnoafričkog društva tijekom prve polovice 90-ih godina prošloga stoljeća koje su uvjetovale ovakav oprezan i stupnjevit prilaz zadatku demokratske tranzicije. Opsežan i temeljit pristup njihova prikaza svakako prelazi opsege ovoga rada. Međutim, može se zaključiti da naglost i brzopletost u procesu odbacivanja aparthejda i njegove zamjene ustavno-demokratskim institucijama ni u kojem slučaju nisu bile uputne. Politički vođe ispravno su uvidjeli nužnost uporabe prijelaznih mehanizama.

\subsection{Nova institucionalno-pravna rješenja}

Već smo prije opisali ustrojavanje Ustavnog suda, kao i njegovu ulogu u procesu tranzicije. Međutim, iako najznačajniji, Ustavni sud nije ni u kom slučaju jedini institucionalno-pravni mehanizam uspostavljen za navedene potrebe. Najprije, u tu svrhu poseglo se za nekim novim zakonodavnim rješenjima kojima je uspostavljen institucionalno-pravni okvir pogodan za što uspješnije provođenje tranzicijskog procesa. Tako je 1993. g. donesen Transitional Executive Council Act kojim je uspostavljeno Transitional Executive Council (TEC), dakle izvršno tijelo koje je imalo ulogu stvoriti ,pogodno okruženje za slobodno političko djelovanje i održavanje slobodnih i demokratskih izbora“". ${ }^{34}$ Nadalje, iste godine, također u svrhu omogućavanja poštenog demokratskog nadmetanja na slobodnim izborima, doneseni su i Independent Media Commission Act, Independent Broadcasting Authority Act i Independent Electoral Commission Act, a početkom 1994. g. donesen je i Electoral

30 Heinz Klug: „Constitution-Making, Democracy and the Civilizing of Unreconcilable Conflict: What Might We Learn from the South African Miracle?", Wisconsin International Law Journal, Vol. 25, No. 2, Summer 2007; Univ. of Wisconsin Legal Studies Research Paper No. 1046, str. 3; preuzeto sa: https://papers.ssrn.com/sol3/papers.cfm?abstract_id=987302 - 19. II. 2018.

31 Detaljnije o ovome ,,dvostupanjskom procesu“ tranzicije vidjeti u: Heinz Klug: „South Africa’s Experience in Constitution-Building“, April 2011, Univ. of Wisconsin Legal Studies Research Paper No. 1157, str. 6-16; preuzeto sa: https://papers.ssrn.com/sol3/papers.cfm?abstract_id=1808168 - 19. II. 2018. g.

32 Hugh Corder: op. cit. (bilj. 14); str. 491-492.

33 Ibidem.

34 Ibidem, str. 506. 
Act.$^{35}$ Pravnim reguliranjem političko-izbornih procesa i uspostavljanjem institucija za njihovu provedbu i zaštitu ${ }^{36}$ stvoreni su uvjeti za održavanje prvih demokratskih izbora, koji su, kako je već napisano, održani u travnju 1994. g. ${ }^{37}$

Naravno, osim ovih zakonodavnih rješenja, u istu svrhu trebao je poslužiti, kako smo već i naveli, Provizorni ustav donesen 1993. g. Poseban značaj i uloga, kada govorimo o Provizornome ustavu, svakako pripadaju njegovim načelima za koja je određeno da moraju biti inkorporirana u tijelo novoga Ustava. Ipak, osim određenja osnovne strukture novog ustavnog uređenja, ova su načela trebala predstavljati svojevrsni ,pravni most“"38 između Provizornog ustava, koji nije donijelo tijelo koje ima izborno-demokratski legitimitet, te novoga Ustava koji je morao donijeti Parlament čiji će sastav biti određen sukladno rezultatima demokratskih izbora iz travnja 1994. g. Nadalje, kako navodi Heinz Klug, definiranje i donošenje tih ustavnih načela, zajedno s gore navednom uspostavom pravnog i institucionalnog okvira za demokratsku tranziciju, omogućilo je održavanje pravnog kontinuiteta između „starog režima“ i novog sustava koji će baštiniti ustavno-demokratske vrijednosti, ${ }^{39}$ a to je bio jedan od uvjeta da bi vladajući uopće i pristupili pregovaračkom procesu. ${ }^{40}$

Na kraju, možemo dodati kako su akteri ovih državnih i društvenih promjena bili itekako svjesni tamne prošlosti staroga aparthejdskog režima, ali i važnosti neponavljanja pogrešaka. Bili su svjesni da bilo kakva odmazda ili osveta ne samo da bi bila korak unazad, nego bi bila korak u neminovnu propast. Najočitiji dokaz koliko su svega toga bili svjesni jest preambula Provizornog ustava kojom se proklamira jednakost svih ljudi, neovisno o spolu ili rasi, te jamčenje zaštite i uživanja temeljnih prava i sloboda za sve..$^{41}$ Nadalje, u cilju društvene pomirbe i prevladavanja, osnovana je Komisija za istinu i pomirenje koja je trebala otkriti istinu o slučajevima kršenja ljudskih prava tijekom aparthejda. ${ }^{42}$ Sve to imalo je za cilj ostvariti da namjera za tranzicijom političkog uređenja, započeta u pravnoj sferi, dobije svoju realnu snagu i u društvenim procesima. Uostalom, stara je istina da pravni propisi, ma kako lijepo bili sročeni, svoju pravu snagu dobivaju tek kada uistinu zažive.

35 Ibidem, str. 507-511.

36 Više o tome u Heinz Klug: op. cit. (bilj. 30.), str. 9-19.

37 Valja napomenuti kako je većina ovih pravnih rješenja, kao i tijela koja su njima uspostavljena, samo prijelaznog, provizornog karaktera. Dakle, njihovo postojanje, baš kao i postojanje Provizornog ustava, bilo je unaprijed vremenski određeno. O tome vidi u: Hugh Corder: op. cit. (bilj. 14); str. 523-524.

38 D. J. Brand: op. cit. (bilj. 10), str. 9.

39 Više o tome u Heinz Klug: op.cit. (bilj. 31), str. 4.

40 Hugh Corder: op. cit. (bilj. 14), str. 522-523.

41 https://www.gov.za/documents/constitution/constitution-republic-south-africa-act-200-1993 - 19. II. 2018. g.

42 Joshua Doherty: Radical Transformation: The Role of the Judiciary in Post-Apartheid Transitional South Africa, str. 5, 2012.; preuzeto sa: https://papers.ssrn.com/sol3/papers.cfm?abstract_id=2230225 19. II. 2018. 


\subsection{Komparativni uzori južnoafričkog iskustva}

Navedeni postupak i pristup tranziciji u ustavno-demokratski sustav u slučaju JAR-a nikako nisu jedinstvena, niti nova pojava. Štoviše mnogi od gore spomenutih mehanizama svoje su uzore imali u drugim, otprije poznatim slučajevima. Uostalom, pojedini autori već su zapazili kako postoji „sve impresivnija grupa 'putujućih pitanja', koja u dinamičnoj migraciji ustavnih ideja, kroz ustavni bricolage, odnosno ustavno posuđivanje, ostavljaju sve uočljiviji trag u ustavnom inženjeringu i karakteristikama novih ustava“" ${ }^{43}$ a njihovim predmetom mogu biti: ,,institucije, tekstovi, presedani, procedure, politička teorija na kojoj se temelje ustavi, ustavni ciljevi i aspiracije“". ${ }^{44}$ Tako je i Južnoafrička Republika primijenila neka od ranijih iskustava drugih zemalja kako bi uspješno prebrodila svoj tranzicijski proces, ujedno osvjetljavajući put nekim drugim državama koje pokušavaju započeti svoje vlastito putovanje što će ih naposljetku dovesti u zajednicu država koje baštine ustavnodemokratsku tradiciju te gaje i razvijaju njene vrijednosti. Pogledajmo sada pobliže koje su od „ustavnih ideja“ implementirane u slučaju JAR-a. Naravno, uz opasku i upozorenje da svaki konkretni slučaj zaslužuje vlastitu prosudbu, a primjena i „uvoz“ rješenja iz drugih sustava nužno zahtijevaju prilagodbu novom okruženju i kontekstu poštujući njegove specifičnosti i ograničenja koja iz toga proistječu. ${ }^{45}$

Usprkos mnogim rješenjima koja su JAR-u poslužila kao uzor u naporima na putu izgradnje ustavno-demokratskog sustava, ${ }^{46}$ posebice se $\mathrm{u}$ tome isticao Ustavni sud koji je mnogo puta posegnuo za inozemnim izvorima u svojoj jurisprudenciji. ${ }^{47}$ Međutim, ovdje ćemo najviše pozornosti posvetiti Provizornome ustavu kao takvome, ali prije toga osvrnut ćemo se na sama ustavna načela sadržana u njemu

43 Arsen Bačić: „Ustavne promjene kao refleks migracije ustavnih ideja i mogućnosti utjecaja na konstitucionalizam, identitet i različitosti Republike Hrvatske“, No. 17, listopad 2011., str. 191; preuzeto sa: https:/hrcak.srce.hr/index.php?show=clanak\&id_clanak_jezik=110635 - 20. II. 2018. g.; na ovome mjestu prof. A. Bačić referira se na sljedeće izvore: Vick $\vec{i}$ C. Jackson: „Constitutional dialogue and human dignity: states and transnational constitutional discourse", Montana Law Review, 65/2004., p. 15 et passim; N. Tebbe \& R. Tsai: „Constitutional borrowing”, Brooklyn Law School Legal Studies Research Papers, Research Paper No. 145, November 2009. (electonic copy available at: htt p://ssrn.com/ abstract=1392122); D. Schneiderman, „Exchanging constitutions: constitutional bricolage in Canada”, Osgoode Hall Law Journal, Vol. 40, Nos. 3-4, 2002; The migration of constitutional ideas, Edited by Sujit Choudry, Cambridge University Press, 2009., p. 448.

44 Ibidem, str. 198.

45 Slično: Heinz Klug: op. cit. (bilj. 31.), str. 5.

46 Primjerice, Ustav u čl. 39. koji se odnosi na tumačenje Povelje o pravima izričito određuje kako sudovi pri tumačenju Povelje o pravima moraju uzeti u obzir međunarodno pravo, a mogu uzeti u obzir inozemno pravo. Vidi: čl. 39 (1) Constitution of the Republic of South Africa-dostupno na: https://www. gov.za/documents/constitution/chapter-2-bill-rights - 20. II. 2018. g.

47 Za uporabu inozemnih presedana u odlukama Ustavnog suda vidi: Christa Rautenbach ,South Africa: Teaching an 'Old Dog'New Tricks? An Empirical Study of the Use of Foreign Precedents by the South African Constitutional Court (1995-2010)“(July 18, 2013). Groppi T. and Ponthoreau M-C (eds) The Use of Foreign Precedents by Constitutional Judges (Hart Publishing 2013), Oxford, UK., str,. 185-209. Preuzeto sa: https://papers.ssrn.com/sol3/papers.cfm?abstract_id=2295493 - 20. II. 2018. g. i Ursula Bentele „Mining for Gold: The Constitutional Court of South Africa's Experience with Comparative Constitutional Law“, 37 Ga. J. Int'1 \& Comp. L. 219, 2009.; preuzeto sa: http://heinonline. org/HOL/Page?handle=hein.journals/gjicl37\&div=11\&start_page=219\&collection=journals\&set_as_ cursor $=5 \&$ men tab $=$ srchresults -20 . II. 2018. 
koja su određena, kako smo već naveli, predstavljati samu srž i bit budućeg, trajnog Ustava. Najprije valja spomenuti kako navođenje ustavnih načela u Provizornome ustavu kao obvezujućeg temelja budućeg Ustava zasigurno predstavlja izniman slučaj u ustavotvornome postupku. Doduše, svojevrsni ,presedan“ ${ }^{“ 48} \mathrm{u}$ tome smislu predstavlja slučaj Namibije iz 1989. g. kada je ustavotvorna skupština ove zemlje u studenome 1989. g. prihvatila načela sadržana u Rezoluciji 435. Vijeća sigurnosti UN-a iz 1982. g kao okvir za donošenje novog ustava ove države. ${ }^{49}$ Međutim, razlika između ova dva slučaja leži prvenstveno u tome što, kada govorimo o načelima Provizornog ustava, ona su bila obvezujuća za ustavotvorca u postupku donošenja novog ustava, dok načela sadržana u navedenoj Rezoluciji Vijeća sigurnosti nisu imala obvezujući nego tek usmjeravajući karakter. ${ }^{50}$

Glede donošenja ustavnog dokumenta provizorne naravi, bez obzira na razloge takve njegove ograničenosti u vremenu, možemo vidjeti da je ta „ustavna ideja“ prisutna još od antike i Aristotelova „Ustava atenskog“, ${ }^{51}$ ali i u razmišljanjima Thomasa Jeffersona, ${ }^{52}$ jednog od „očeva utemeljitelja“. Na ovome mjestu nešto više pozornosti zadržat ćemo na Temeljnom zakonu (njem. Grundgesetz), tj. Ustavu SR Njemačke ${ }^{53}$ (dalje: TZ), koji je, ako već ne najglasovitiji, onda svakako jedan od najreprezentativnijih takvih provizornih ustavnih dokumenata. Dakle, TZ je zamišljen kao prijelazni, provizorni mehanizam koji će, nakon što demokratski temelji poslijeratne njemačke države očvrsnu, svoje mjesto ustupiti novom, trajnom dokumentu, a on sam će postati dio povijesti. ${ }^{54}$ Međutim, ova priča je u povijesnoj zbiljnosti ipak drugačije ispričana. Nema sumnje da je TZ svoje mjesto u povijesti zauzeo, ali ne zbog toga što je iščezao, kako mu je bilo namijenjeno, nego upravo suprotno, zato što je uspio nadvladati zlu kob vlastite sudbine i namijenjenu mu prolaznost. Štoviše, ne samo da je uspio „preživjeti“ proces demokratske tranzicije, nego je ostao kao trajan ustavni okvir nanovo ujedinjene njemačke države. Veliku ulogu u tome svakako je odigrao Savezni ustavni sud koji je svojom judikaturom priskrbio Temeljnom zakonu naslov „velikog njemačkog ustava“,55 a sebi pak

48 Hassen Ebrahim, Laurel E. Miller: op. cit. (bilj. 18.), str. 127.

49 Više o tome u: Marinus Wiechers: „Namibia's Long Walk to Freedom - The Role of Constitution Making in the Creation of an Independent Namibia“; u: Laurel E. Miller, Louis Aucoin (ed.): Framing the State in Times of Transition-Case Studies in Constitution Making, str. 85, United States Institute of Peace Press, Washington, D.C., 2010., preuzeto sa: https://www.usip.org/sites/default/files/Framing\%20the\%20 State/Chapter4_Framing.pdf - 20. II. 2018. g.

50 Hassen Ebrahim, Laurel E. Miller: op. cit. (bilj. 18), str. 127.

51 Navedeno prema: Ozan O. Varol: „Temporary Constitutions“, 102 Cal. L. Rev. 409 (2014), str. 413; preuzeto s:http://heinonline.org/HOL/Page?handle=hein.journals/calr102\&div=16\&start page $=4$ 09\&collection=journals\&set_as_cursor $=9 \&$ men_tab $=$ srchresults -20 . II. 2018. g., Usp. Aristotle: „The Athenian Constitution“", part 31; pristup na: http://classics.mit.edu/Aristotle/athenian_const.2.2.html - 20. II. 2018. g.

52 Ozan O. Varol: op. cit. (bilj. 51), str. 413.

53 Temeljni Zakon donijelo je Parlamentarno vijeće 23. svibnja 1949. g.

54 Usp. Justin Collings: Democracy's Guardians - A History of the German Federal Constitutional Court, 1951-2001, Oxford University Press, 2017., str. XV-XVI.

55 Citirano prema: Jasna Omejec: „Veliki njemački ustav $i$ nepromjenjiva ustavna načela u praksi Saveznog ustavnog suda“, str. 1.; preuzeto sa: https://bib.irb.hr/datoteka/792156.OMEJEC_GRUNDGESETZ_-ZZbornik_PRAVO_I_PRAVDA,_2015.,_PFBgd.pdf - 20. II. 2018. g. 
dodijelio titulu ,čuvara ustava.“" ${ }^{\text {“6 }}$ Ovaj „,gigant iz Karlsruhea“, kako običavaju nazivati Savezni ustavni sud, doista je tijekom svoga postojanja učinio mnogo na razvoju ustavno-demokratskih standarda u SR Njemačkoj. ${ }^{57}$

\subsection{Ustavni sud kao arhitekt $i$,čuvar" ustavno-demokratskog zdanja}

Kao što smo već vidjeli, Ustavni sud JAR-a, od samoga je početka imao, iako sličnu ulogu, ipak ponešto drugačiji zadatak u stvaranju demokratsko-ustavnog okvira JAR-a. Za razliku od svoga njemačkog uzora, ${ }^{58}$ ovaj je Ustavni sud stariji od ustavnog dokumenta što ga ima dužnost štititi. ${ }^{59}$ Kao što već znamo, Ustavni je sud uspostavljen odredbama Provizornog ustava koji je već od početka u sebi nosio pečat svoga kraja ${ }^{60}$ a uloga Ustavnog suda bila je prvenstveno u zaštiti ustavnih načela koja su morala biti inkorporirana u novi Ustav. Dakle, uspostava Ustavnog suda prethodila je donošenju novoga Ustava. Zato je, kao što smo već ustvrdili, Ustavni sud sudjelovao i u postupku donošenja novoga Ustava, jamčeći da će sama bit i suština Provizornoga ustava nastaviti ,„̌ivjeti“ zaogrnuta ruhom novog Ustava. Stoga, Ustavni sud štitio je novi Ustav, odnosno samu njegovu bit sadržanu u njegovim načelima, još u vrijeme kada je ovaj Ustav bio samo misao u umu onih na čijem je srcu ležala želja za slobodom. Imajući u vidu ovakvu ulogu Ustavnoga suda, može se lako zaključiti koliki je njegov značaj u donošenju novog Ustava, ali i u cjelokupnom procesu demokratske tranzicije JAR-a. Uostalom, ,ustav samo postavlja okvir u kojem se ima provesti proces društvene preobrazbe... a u svemu tome suci su zaduženi za zaštitu ljudskih prava i nadzor nad vladajućim“". ${ }^{61}$ Svjesni svega ovoga, neki su autori (Hassen Ebrahim, Laurel E. Miller) ustvrdili kako su „novoimenovani ustavni suci koji su morali biti reprezentativni u smislu proporcionalne zastupljenosti glede rase i spola, zajedno sa transparentnošću njihova izbora, trebali poslužiti svrsi ostvarenja ideala demokratske tranzicije. "62

56 Justin Collings: op. cit. (bilj. 54), str. XXXV i 1.-2.

57 Ibidem, str. 286-290.

58 Naravno, ovdje smo Savezni ustavni sud naveli samo kao jedan od mogućih komparativnih primjera kada Ustavni (ili pak, u nekim drugim državama Vrhovni) sud zauzima poziciju ,čuvara ustava“, a posebice njegovih temeljnih načela. Primjerice, za ulogu Vrhovnog suda Indije u razvoju doktrine „,basis structure“ (ili basic features“) vidi: Arun K. Thiruvengadam: „The Constitution of India - a Contextual Analysis“, Hart Publishing, Oxford and Portland, Oregon, 2017., str. 220-229; navedeni naslov dio je serije publikacija: Constitutional Systems of the World - General Editors: Benjamin L. Berger, Rosalind Dixon, Andrew Harding, Peter Leyland and Heinz Klug, Bloomsbury Publishing Plc, London, UK.

59 Savezni ustavni sud uspostavljen je 1951. g., a TZ je donesen 1949. g., s druge strane Ustavni sud JAR-a uspostavljen je 1994. g., a novi Ustav donesen je 1996. g.

60 Čl. 73. st. 1. Provizornog ustava; dostupno na: https://www.gov.za/documents/constitution/ constitution-republic-south-africa-act-200-1993\#GENERAL\%20AND\%20TRANSITIONAL\%20 PROVISIONS - 21. II. 2018.

${ }^{61}$ Susannah Cowen: Judicial selection in South Africa, Democratic Governance and Rights Unit, 2013., str. 57.

${ }^{62}$ Hassen Ebrahim, Laurel E. Miller: op. cit. (bilj. 18), str. 140; H. Ebrahim i L. E. Miller na ovome mjestu se pozivaju na: Carmel Rickard: „The Certification of the Constitution of South Africa“ u: The Post-Apartheid Constitutions, p. 224-225. 
Naposljetku, nema dvojbe oko toga da je Ustavni sud od samog nastanka djelovao u skladu s Kelsenovom zamisli o ustavnom sudu koji je „čuvar ustava“ kao izvora najvišeg prava u državi ${ }^{63}$ Vidjeli smo i da je tu svoju ulogu počeo obavljati i prije donošenja samog Ustava, štiteći njegovu, Provizornim ustavom zajamčenu, suštinu iskazanu u načelima, a koja, pak, predstavljaju, kako je već kazano, ,pravni most“ između dvaju ustava. Međutim, treba imati na umu da se „,demokracija izgrađuje postupno tijekom vremena, u interakciji prosvijetljenog vodstva i aktivnog građanstva"64 pa se stoga ni uloga Ustavnog suda ne iscrpljuje u određenom trenutku i određenim činom. Naprotiv, njegova dužnost i obveza iz povjerene mu zadaće jest obavljati na trajnoj osnovi te na taj način pratiti, ali i usmjeravati, razvoj države i društva na njihovu putu obliježenom naporima u svrhu dostizanja i ozbiljenja ustavno-demokratskih vrijednosti. Stoga je pred Ustavnim sudom još uvijek zadatak da razvija ustavno-demokratsku strukturu države koje je dijelom i on sam bio arhitekt.

Međutim, ovdje i na ovome mjestu nećemo se upuštati u daljnji pregled jurisprudencije i prakse Ustavnog suda u razdoblju koje je uslijedilo nakon donošenja novog Ustava krajem 1996. g. i njegova stupanja na snagu početkom 1997. g., jer to uvelike prelazi okvire, ali i svrhu ovoga rada. Naime, naša je namjera bila samo dodatno osvijetliti proces tranzicije u onim prvim godinama kada je sam Ustavni sud imao zasigurno jednu od odlučujućih uloga, i to ne samo u zaštiti ustavnopravnoga sustava nego je uzeo učešća i njegovu kreiranju. Specifičnost takve uloge Ustavnog suda zapravo je proizašla iz samog opredjeljenja aktera tranzicije koji su, ispravno uvidjevši težinu i kompleksnost zadatka koji je pred njima, posegnuli za stupnjevitom tranzicijom koja je iznjedrila dva ustava i jedan skup ustavnih načela koji su činili „pravni most“ između njih, a Ustavni sud je u svemu tome bio postavljen za „,̌uvara“ toga „mosta“. Naravno, nakon što je osigurao siguran prijelaz iz staroga sustava u novi, njegova uloga ostaje i dalje da budno motri nad oživotvorenjem ideala vladavine prava i ustavno-demokratskih vrijednosti, ali, kako smo već kazali, to je tema koja izlazi iz okvira ovoga rada, te kao takva mora biti istražena i ispričana na nekom drugom mjestu.

\section{ZAKLJUČAK}

Proces tranzicije koji je u Južnoafričkoj Republici započeo nije bio lagan te je od svih sudionika zasigurno iziskivao velike napore u svrhu uspješnog provođenja. Kao što smo mogli vidjeti, u mnogome su se njegovi pokretači i kreatori poslužili već otprije poznatim pravnim i institucionalnim rješenjima koja su potom prilagodili

63 Hans Kelsen: The Nature and Development of Constitutional Adjudication, navedeno prema: Lars Vinx: op. cit. (bilj. 3), str. 44-47.

64 Branko Smerdel: „Konstitucionalizam i promjena vlasti“, Zbornik PFZ, 50, 1-2, str. 29., preuzeto sa: http://heinonline.org/HOL/Page?men_tab=srchresults\&handle=hein.journals/ zboprvfaz50\&id $=30 \&$ size $=2 \&$ collection $=$ journals \& terms $=$ Konstitucionalizam $\% 20 \mathrm{i} \% 20$ promjena $\% 20$ vlasti\&termtype $=$ phrase\&set as cursor $=3-22$. II. 2018. 
uvjetima u društvenoj zbilji JAR-a. Međutim, na isti način kako je JAR posudio neke od ,ustavnih ideja“ i ugradio ih u svoje iskustvo, neka od rješenja i iskustava njegova tranzicijskog procesa mogu poslužiti kao uzor za druge države koje smjeraju krenuti putem vlastite tranzicije. Na zasadama postojećih iskustava i rješenja proizašlih iz njih rađaju se i razvijaju neka nova. Alan Watson zaključuje da „migracije ideja“65 predstavljaju ,najplodniji izvor (pravnog) razvitka“ . ${ }^{66}$ Naravno, iako se neka ,ideja“ $i$, posljedično, instrumentarij proizašao iz njene primjene može pokazati kao izvrsno rješenje za neku situaciju, uvijek pri njezinu novom preuzimanju i implementaciji valja biti oprezan. Jer, iako sama zamisao može biti već viđena i prokušana, njena primjena na novi slučaj i u novoj okolini ipak poziva na oprez i zahtijeva originalnost.

Ono što se nama čini najzanimljivijim izdvojiti iz južnoafričkog primjera jest navedena postupnost pri uvođenju novih pravnih i institucionalnih rješenja i pri tome uporaba prijelaznih (provizornih) rješenja. Kao što smo vidjeli, to je bio slučaj počevši od najvišeg pravnog akta - Ustava, pa sve do drugih zakonodavnonormativnih rješenja koja su imala poslužiti za amortiziranje neizbježnog trenja na neizvjesnom tranzicijskom putu. U primjeru JAR-a ,ustav je poslužio kao simbol velike političke tranzicije u državi““ ${ }^{67}$ odnosno simbol „,novoga početka“68 ili točka razgraničenja na vremenskoj lenti ,između 'Prije' i 'Poslije" “69 u političkoj povijesti JAR-a. Prema riječima B. Ackermana, upravo slučaj ,the new beginning scenario“, kakav je bio u JAR-u, može pretvoriti ustav u simbol koji ima veliku ulogu u izgradnji novoga političkog identiteta države..$^{70}$ Međutim, u svemu ovome valja izdvojiti, i naglasiti, ulogu koju je, kako smo vidjeli, imao Ustavni sud u nadgledanju, usmjeravanju, ali i u kreiranju ovoga razvojnog procesa.

Mislimo da je navedeni pristup JAR-a u realiziranju tranzicijskog procesa, koji $\mathrm{u}$ sebi istovremeno nosi i postupnost, ali i temeljitost, zajedno sa strpljenjem u egzekuciji i primjeni istoga, svakako nešto na što bi druge države koje se i same nalaze u procesu tranzicije (ili u njima tek sazrijeva odluka da pođu njime) trebale obratiti pozornost te učeći na primjeru JAR-a i same pokušale iznaći odgovarajuće rješenje koje će im omogućiti uspjeh. Naravno, pri svemu tome ne smije se izgubiti iz vida činjenica da ,za napredovanje demokracije i vladavine prava... nedvojbeno je potrebno stabilizirati ustavne institucije " ${ }^{71}$ te stoga posebno treba obratiti pozornost na temeljitu pripremu prilikom njihova stvaranja i oblikovanja, kako bi

65 Arsen Bačić: op. cit. (bilj. 43), str. 192.

66 Citirano prema: Arsen Bačić: op. cit. (bilj. 43), str. 192.

67 Bruce Ackerman: „The Rise of World Constitutionalism“ (1996.). Occasional Papers. Paper 4, str. 5; preuzeto sa: http://digitalcommons.law.yale.edu/cgi/viewcontent.cgi?article=1005\&context=ylsop papers - 5. III. 2018.

68 Ibidem.

69 Ibidem, str. 6.

70 Ibidem, str. 8.

71 Branko Smerdel: „Hrvatski pravni sustav i ustavno načelo vladavine prava“, 51, Zbornik

PFZ 1149 (2001.), str. 1151; preuzeto sa: http://heinonline.org/HOL/Page?handle=hein.journals/ zboprvfaz $51 \&$ div $=80 \&$ start $\_$page $=1149 \&$ collection $=$ journals\&set_as_cursor $=0 \&$ men_tab $=$ srchresults 22. II. 2018. 
se izbjegli nepotrebna lutanja i gubitak vremena u tome procesu. Ipak, ovaj gore navedeni racionalni zahtjev za stabilnošću ustavnih institucija u vremenu tranzicije valja pomiriti s realnim potrebama društva koje se mijenja u nastojanju ozbiljenja ustavno-demokratskih ideala. Upravo bi Ustavni sud, kako u slučaju JAR-a, tako i u drugim tranzicijskim državama, imajući u vidu ugled i značaj te institucije, trebao poslužiti kao korektor naglih promjena ili pak suprotne tendencije koja bi se ogledala u petrificiranju postojećeg stanja koje ne bi bilo u mogućnosti pratiti potrebe društvenog razvoja.

\section{SIGNIFICANCE AND ROLE OF THE CONSTITUTIONAL JUDGE IN DEMOCRATIC TRANSITION- THE EXAMPLE OF THE REPUBLIC OF SOUTH AFRICA}

The Constitutional Court, since the introduction of this institution into the legal system, has played a significant role in the legal constitutional system. With time the importance of this institution has increased. Thus, the Constitutional Court has slowly become an unavoidable participant in the creation of the most important political and legal processes in the country. One of the most obvious examples of the wide significance of the Constitutional Court is the case of the democratic transition in the Republic of South Africa during the 90's of the last century. That is, then the Constitutional Court of the Republic of South Africa played one of the main roles in directing and in creating the new legal constitutional framework the aim of which was to ensure a successful transition. Actually, it can be said that the Constitutional Court itself participated in the creation of this new constitutional order which certainly represented a rare example of such a role of this institution in the whole process of the constitutional construction of a country. Naturally, apart from the Constitutional Court other institutional and legal mechanisms were established in the aim of a smoother and more successful transition from apartheid to democracy. Many of them were taken from other systems and adapted to the needs and social circumstances of the Republic of South Africa. Consequently, the experience of this country and its solutions could be an example to look up to for other countries in the process of their own democratic transition.

Key words: Constitutional Court, Republic of South Africa, transition, constitution, constitutional principles 